IBIMA Publishing

Journal of North African Research in Business

http://www.ibimapublishing.com/journals/JNARB/jnarb.html

Vol. 2016 (2016), Article ID 793075, 20 Pages

DOI: $10.5171 / 2016.793075$

Research Article

\title{
Practices of Territorial Marketing in Morocco: A Study of the Experience of Tangier
}

\author{
Fadoua Laghzaoui and Mostafa Abakouy \\ University of Abdelmalek Essaâdi, Tangier, Morocco
}

Correspondence should be addressed to: Mostafa Abakouy; mabakouy@yahoo.fr

Received date : 3 March 2015; Accepted date : 27 November 2015;

Publisher date : 26 September 2016

Academic Editor: Ikram Radhouane Fgaier

Copyright (C 2016. Fadoua Laghzaoui And Mostafa Abakouy. Distributed under Creative Commons CC-BY 4.0

\begin{abstract}
The purpose of this research is to discuss the territorial marketing and analyze its application to the city of Tangier. Our approach was, firstly, to seize the regional marketing effort of Tangier in its temporal dynamics (Past-present-future) and, secondly, to decline this marketing: marketing to residents, tourism marketing and marketing to investors. The main results of our research show that marketing as designed and conducted in Tangier is insufficient and unsatisfactory. Such shortcomings have led us to formulate recipes that can improve the image, attractiveness and competitiveness of the city.
\end{abstract}

Keywords: Territorial Marketing, Tangier, Tourism Marketing, Attractive Investment, Welfare of Citizens

\section{Context and the Problematic of De Research}

In Morocco, the affirmation of the existence of territorial regimes throughout time has corresponded not only to periods of political stability but also to economic progress.

Since the middle of the 1990s and particularly since the announcement of the advanced regionalization, regions have been entrusted with new missions. Thus one can predict that the evolution of Morocco rests on the region and that de state with territorial organization is substituted for the unitary state. Our research on the marketing of regions will be seen directly in this perspective.

Currently, the city of Tangier takes up the second rank in terms of the size of economic projects as well as the second position in touristic earnings. The city in fact arouses an exceptional enthusiasm leading to the requalification of the city

Cite this Article as: Fadoua Laghzaoui And Mostafa Abakouy (2016), " Practices of Territorial Marketing in Morocco: A Study of the Experience of Tangier ", Journal of North African Research in Business, Vol. 2016 (2016), Article ID 793075, DOI: 10.5171/2016.793075 
(royal solicitude, the establishment of great projects of development such as Tangier Med, the reinforcement of reception infrastructure of the new industrial zones as well as that of the free zones for exportation, etc.). The city has several assets (having a geographical proximity from Europe, being at the crossroads of the great axes of international exchanges, enjoying a prestigious history and a fascinating beauty of the panoramas, etc.)

The purpose of our research is to know to what extent the Tangerine territory is ready to come within the framework of a logic founded on the improvement of performances and the quest of image. Such performances and such an image lie on tools that have proved their efficiency in terms of enterprise culture such as marketing and strategic management.

Although territorial marketing had been sketched for several decades, it was only in the 1980s that it was revisited and reconsidered. It constitutes a sort of extension of marketing of the organizations, dedicated to a wider scale to a territory which might be an urban center, a city or a group of cities and their suburbs, a country, even yet a group of countries. However, it presents specificities as to the approach to adopt and the tools to use. By and large, it is addressed to three types of customers: residents, investors or enterprises and tourists. Similar to corporate marketing, territorial marketing mobilizes several foundations of diverse disciplinary fields like economic geography, public management, sociology, geo-strategy, the theory of the stakeholders, public-private partnership, territorial planning, or local development.

In our attempt to alternate between theoretical schemes and lived practice by taking the territory of Tangier as a fulcrum, we will try to analyze the reflection and the action of the interested actors in the image of the Tangerine territory, its attractiveness and thus its competitiveness. More precisely, we are ambitious to answer the following queries:
- Is it possible to "market" adequately the city of Tangier?

- Do we have a clear vision between the different organs of the local governance?

- Do we reason in terms of global and regional development of which Tangier would be away of access and reception?

- Do we know how to exploit sufficiently its enormous potentialities?

\section{The Research Interests}

The undertaking of this investigation is explained by the following motives:

In order to perpetuate their economic and social activities, cities are condemned to build very precise strategies of development that require advanced tools of management.

- The elaboration of a management dashboard of the city can occasion a return to the strengths and weaknesses to improve and hence to their capacity to induce adequate political actions, i.e. multiform strategies of development affecting as much issues related to infrastructures as the questions of the managerial, marketing and communicational type.

Up to this day there is a conceptual and practical almost gap in terms of marketing strategy of the cities. The investigations that were carried out exploit global statistics and the practical solutions stem more from intuition than reliable and systematic evaluation.

We feel here that there is a niche of importance to exploit. In Tangier, there are university professors and academics whose axes of research are related to sustainable development and marketing strategies. Besides, the current local governance is entrusted to a staff predisposed to elaborate a vision of sustainable development for the city of Tangier (City Hall, Regional Council of Tourism, Regional center of Investment, Chamber of Commerce, Industry and services, Wilaya, etc.). 
- The results of such research can have effects on the teaching of marketing as well as on the strategic management of territories.

\section{Methodology and framework}

Our research complies with the following process:

- Documentation research and overview of the literature on territorial marketing and on local public strategic management.

- Development of assessment tools of the marketing approach to cities.

- Making contacts and interviews with concerned actors and organizing surveys with target audiences. The aim being to introduce all to the problematic of territorial marketing.

- Data keyboarding, processing and interpretation, leading to the writing of a final report that could be the subject of an article to be published in a scientific journal.

By association of the context and the problematic of the research, as well as its interests and methodology, we have structured our paper by adopting the framework hereafter:

In the first place and after a synthesis of its meaning, its keywords, its issues, its dimensions...we plan to identify the landmarks of the territorial marketing and mobilize various foundations, theories, disciplines which serve as aspiratory sources for it.

In the second place, we will try to analyze the practice of marketing of the Tangier territory in its three times: yesterday's gestation, today's manifestations and tomorrow's changes. The presentation of the different obtained results is preceded by the explanation of our approach of collecting and analysis of information.

Territorial marketing versus common marketing
The history of marketing goes back to the first decades of the $20^{\text {th }}$ century at the time of the work scientific organization, a school advocated by the founders of management (Taylor, Ford, Fayol, ...) as they were inspired by the economists who had preceded them (Smith, Ricardo, Babbage...). This first school gave importance to the customer insofar as it considered that he needs standardized and affordable products at a low price. It was only with the glorious thirty (1950-1970) that the nations recover again some economic prosperity and that within society we started to clearly distinguish at least three types of customers, namely the rich, the moderately rich and the poor, for whom differentiated products had to be matched to correspond to their purchasing power and lifestyle.

The commercial management of companies then passes from an output perspective that must be cleared in the market, to a marketing perspective which consists in finding out the requirements of the market even before starting to produce.

Since then, marketing has extended to special cases such as industrial marketing (B to $B$ instead of $B$ to $C$ ), strategic marketing (a marketing planned for a distant future against a short-term vision); International marketing (a marketing dedicated to international markets versus a domestic marketing), etc. It is from the 1980 s that we started to integrate the territorial marketing.

It is almost banal to remind that marketing is a process that articulates five basic steps: the informational marketing (where the company is invited to learn about the consumers' behaviors and competitors' maneuvers); the strategic marketing (where it defines the criteria of market segmentation in order to determine the number of segments to target and to know how to position above); operational marketing (where marketers use their art of well "mixing" the product policies price, place, promotion and communication ); the implementation of the different fixed choices (marketing plan) and marketing audit (where the officials control their 
business performances and measure the degree of their customers' satisfaction).

This enterprise culture would inspire territorial officials: mayors of cities, economic- tourist development agencies and urban planners (Baby, 1994 and 1998; Noisette and Vallerugo, 1996; Hatem, 2007; Meyronin, 2012, etc.). We must say that this territorial marketing as a practical behavior has not been sufficiently accompanied by academic research.

This paragraph is not intended to establish a statement of the art in this field (lack of space, but also because this paper is divided into three areas: analysis of the attractiveness with regard to a- residents, b- tourists and c-investors ),but rather to give us an image (picture) of territorial marketing in comparison with corporate marketing. More specifically, we will try to locate the former to the latter by seeking their divergences and convergences.

\section{Corporate marketing: an inspirational source for territorial marketing}

Throughout the concatenation of corporate marketing, one perceives that it can be easily transposed to the marketing of territories. To be "marketed ", these adhere to the same philosophy of corporate marketing.

- Marketing is primarily a state of mind, a mentality that resolutely requires a reflex of extroversion which stipulates the need to open up to the customer whose requirements and preferences make of him a "king" you must know undoubtedly to listen to. This extroversion also advocates that its gains go through customer satisfaction. By analogy, a territory develops a similar attitude by orienting itself on others; otherwise how could it exist without inhabitants, tourists or investors?

- Techniques of attractiveness, seduction, and loyalty are used to achieve their goals.
- We note the existence of competition between territories in order to increase the number of home tourists, investors and residents, in the same way as companies are engaged in a fierce competition to increase their market share.

- We learn that corporate marketing is the subject of a lot of reactivity, since it falls to marketers to imagine the segmentation criteria, to appreciate differently the relevance of the segments to choose, to create the most perceived image by the customers, to have the art of measuring between different commercial actions, to build a marketing plan, to create a marketing dashboard to measure and control the marketing activities, etc.. It is strictly to the image of the territories that are built significantly distinctive identities. They use their own policies and techniques to draw more visitors and satisfy the residents. Their "recipe" of attractiveness is not a simple formula to duplicate in any way. It is rather a distinctive, personal and genuine creation and perfectly adapted to their targets. Do not we find here the same requirements of corporate marketing that invite them to build a "golden triangle" to position themselves?

- The concrete commercial actions are preceded by deep reflections and analysis that result in the establishment of a critical approach to possible solutions.

- In order to build their marketing strategy or undertake their operational actions, marketers resort imperatively to the information before the offer (to identify the customers' desiderates and preferences), the offer (to test their commercial strategies) and after the offer (to measure the degree of satisfaction post -purchase ), almost like the territorial actors and the supervisory agencies that identify in advance the 
needs of residents, tourists and investors, then adjust their budgets and measures over the territorial service provision benefits and finally determine satisfaction surveys to renew their mandates .

- Territorial marketing assigns itself the goal of consolidating economic links as perennial as possible between the territories on the one hand and the different actors concerned on the other. In doing so, territories "mimic" the same corporate marketing model that strives to improve business performances in terms of market share, turnover, profit margin, customer loyalty, etc.

- Similar to the companies that would seek to capitalize their image through the creation of the brand, territories are more and more conscious to create their own by way of real or imagined attributes.This territorial brand would permit, like in the case of companies, to facilitate decision making among customers of a territory and to reassure them. By the effect of globalization, territories (cities, regions, countries,...) endeavor to offer relatively similar offers and the users do not know to which territory to go unless it had a special "touch", a personal "style", a differentiated style and communicate it .

- Corporate marketing has evolved a lot over time. It has moved from transactional approach to a market oriented approach giving more weight to the personalized relationship between the company and its customer segments. Territories have managed their marketing because it was in line with the same relational approach, founded on a personalized treatment of the approached segments and projected over the long term. Is it not of great interest if the tourist visits the territory, extends his stay and returns several times after? Is it not of great interest if the investor, after being implanted in the territory, perpetuates his activities and renews his projects? Is it not of great interest if the resident of a territory accedes to comfort and well-being and intends to stay in it? Besides, the three main segments of territorial marketing (investors, tourists, and residents) express inter and intra -segments needs that are so specific that any standardization of commercial actions is doomed to failure. Only proposals that are made "to measure" are accepted.

\section{Corporate marketing: transposition obstacles to territorial marketing}

Despite the adoption of the same spirit like that of corporate marketing, territorial marketing uses its own specific tools.

- If the marketer in the company has the choice or not to adopt an extrovert approach (monitor market demands and strategies of competitors ), officials of territorial marketing are by nature open on user expectations in terms of local public services.

- With opposition to that a company that exists as a legal person, as an organization that subdivides roles within its structures, as an entity managed by actors aware of their roles within its structures, as an entity managed by actors aware of their strategies and their mobilized resources (the company is thus a subject ), the territory has neither a legal personality nor a clear organization, nor clean conscience (it is therefore an object manipulated by several actors who each tries to assert their power ). As a conscious action, the company can easily control its actions and transactions while the territory does not have enough power to be aware of all the contributors in it, or know all their maneuvers.

- Within the companies, it is
easy to spot (and empower) the 
responsible for the commercial and marketing activities. In the territories, agencies, structures or institutions in change of territorial development are designated, but the responsibility is shared among all the actors of the territory because the territorial offer, instead of being subject to a purchase sale transaction, is conversely, coproduced between each other.

- If in most situations in companies, marketing strategies are confined in triennial plans and rarely quinquennal ones, the time axis of the territories usually exceeds five years.

- In the face of plurality of segments, the company has the choice to target segments that are appropriate to it in terms of their potential, profitability or their sustainability. Territorial marketing managers do not have freedom of choice; they are obliged to refer to all users in all categories.

- In the approach to its market, a company may be limited to the domestic market and they apply only common marketing approach. Conversely, territories have no choice. They address immediately and willy-nilly international customers. In principle, they would apply techniques and strategies of international marketing, which responds to specific stakes and has wider ambitions. In other words, territorial marketing is expensive, but it brings a lot.

- The mobility that marks residents and particularly tourists and international investors makes it different to define the field of intervention of territorial authorities as contrasted with the company that can easily spot and measure its market segments. Moreover, a conventional company may not consider the path to the international and settles on domestic market. The territory is committed immediately and willy-nilly to the international.

- In order to operationalize marketing strategies of a company, marketing-mix is used to attempt a dosage between four policies called $4 \mathrm{p}$ (product, price, place, promotion). The territorial field is not ready to adopt them easily. At first the distribution policy, understood as a logistics that is leading finally to product shipment to the customer, is ineffective in the context of a territory, unless one may consider that it is the user who comes to benefit from territorial service provision; it is the tourist who comes to territory to visit it; it is the resident who comes to the territory to live in it; it is the investor who comes to the territory to settle in it and practice his trade. Then, local officials (supervisory authorities, development agencies, local authorities ...) do not intervene directly to set a pricing policy for the territorial service provision. Finally, ready-for-use products or services are not sold on a territory. Rather, an environment or an atmosphere is offered to the user to conduct his activities.

- If companies must necessarily perform commercial and marketing actions in the territory to generate the interest of potential customers, such actions are based on the profile of local political decision makers. The latter cannot guarantee the effectiveness of their economic development policies because they have just indirect means of actions. Furthermore, the mandated to local development are so plural (supervisory agencies, the region, municipality, business partners, development agencies, etc..) that their lack of coordination leads to monotonous actions unlike the companies which would delegate marketing strategy to a person supposed to be responsible for the degree of relevance of his choices.

- In case of business underperformance, companies could file 
for bankruptcy and disappear. However, a territory can fall into an economic crisis, but will not disappear or be taken over by someone else. Inter-regional cohesion and solidarity allow offsetting the difficulties of some by the prosperity of the others.

\section{Conclusion}

By situating territorial marketing to business marketing, we realize that:

- The first borrows from the second the same philosophy, but it will never be its pure photography.

- It adopts the same reasoning, but it uses its own instruments.

- It is inspired by its universalities, but it keeps in mind its specificities.

\section{Territorial marketing approach of Tangier}

Due to the nature of our theme of research and the information to collect, we adopted a more qualitative than quantitative approach. Although they are limited to a restricted panel of surveyed people, our investigations of the marketing dimension of Tangier area were conducted in a depth manner so that all the people interviewed (each one at this level of responsibility (or participation) could shed light as sufficiently as possible on the question.

As we have "conjugated" our research in the past (gestation), in the present (manifestations) and in the future (mutations), we undertook to meet as many actors of the "three tenses" as possible while operating a kind of benchmark to define the prospective trends.

Primo, we must say beforehand that we have drawn from a large series of documents in the form of press, national or international journals, reports of activities and reports of studies. Such documents were deliberately diversified because we are aware that they do not enjoy the same degree of reliability, truthfulness and objectivity. The techniques of the assessment of information (in terms of relevance for the purposes of one research ) from its source ( in terms of reliability, overlapping ( for more objectivity ) and a sort of "pruning "( because the information was present either as "parasites" or as information or cannibalizing information) have enabled us to fulfill one mission.

Segundo, we, being both regular residents of the city of Tangier for over 19 years now and being also both its visitors for more than two decades, we have based ourselves on our own observations. These observations allowed us to pass judgment on the appeal of Tangier for its different customer segments. In the space of 20 years, Tangier has categorically changed configuration (for certain in the positive direction for others in the negative one.)

Tercio, we have conducted field investigations using questionnaires, interviews and different analysis grids. We preferred to start with the supervisory agencies regarding territorial service provision such as la Société Mobilière d'Ingenierie Touristique (SMIT), the region of Tangier - Tetouan, l'Agence de developpement des Provinces du Nord ( ADPN ), (Development agency of the Northern provinces), the Tangier Regional Council of Tourism (CRT), the Chamber of commerce, Industry and Services of Tangier (CCIS), the Regional Center of investment of Tangier - Tetouan, the region of Tangier - Tetouan, the Tangier City Council, etc. In parallel, we conducted questionnaires with target customers of the territorial offer, in this case investors and contractors, visitors and residents .We indicate that we consulted also some experts (French, Finnish, Swedish, Belgian, Spanish, Italian, etc.... ) of territorial marketing who are invited at least twice to animate seminars on territorial marketing approach in order to share the experience of the cities they have respectively studied.

A diplomatic capital during the first half of the twentieth century and through its free port stations, Tangier was one of the most important financial centers in the world."Dream" and "magic" for some, "paradise" for others, Tangier exercised a real fascination on investors and its 
visitors. Its euphoric eruption had overshadowed rival regions like Liechtenstein, Andorra or Monaco. As a matter of fact, to the influx of capitals was added the influx of ideas making of Tangier a prime destination, or at least a stopping place for the entire European and North American intelligentsia of the epoch (filmmakers, musicians, painters, writers, etc.)

Then, the city plunged into a deep sleep during more than five decades.It had to wait for the highest authorities of the country to be reborn from its ashes and to restore the luster of its prestigious past through essentially Tangier Med and marinas as locomotive and Tangier metropolis as a future promise.

However, the question that arises is whether we have enough imagination and moral forces, financial resources, natural and human to honor its commitments. And since it promises mountains and marvels to its visitors, residents and investors, we would like to restate in a more precise way the question as follows: what is the magnitude of the marketing effort made by the Tangerine territory towards its customers?

The results of our research are divided into three areas, respectively linked to marketing in relation to residents, investors and tourists.

\section{Marketing vis- ̀̀-vis residents}

In principle, marketing aimed at residents has two populations: the residents on site and eventual inhabitants of other regions (national or international) and who could be attracted by the city. Yet, in most cases we address less the potentials (who would be at risk of unemployment and insecurity) than already established inhabitants, striving to improve their quality of life. If the city actors share the same urban space, they are so plural (local authority, citizens, interest groups, NGOs, industrials, merchants , state, governmental organizations, public and semi-public institutions, etc.) that their concerns diverge. The recurring themes of the
Moroccan citizens to express their degree of satisfaction towards urban services are often related to opportunities (or risks ) of employment, services to the population, cost of living, absence or presence of pollution, the magnitude of cultural, sporting, associative activities, territorial planning, the nature of reliefs and climatology, coexistence among citizens, the abundance ( or scarcity) of green spaces, etc. $^{1}$

Eager to stick to the tangerine field, we have conducted a survey of a sample of 160 citizens $^{3}$ of the city which is admittedly slightly representative in the eyes of the statisticians, but we wanted to conduct thorough investigations to get closer to the truth. Since urban service provision is coproduced between suppliers and users, we decided to integrate the judgements of both parties.

Initially, we started by asking the surveyed people to list and classify in a decreasing order the parameters that make their quality of life, basing on the identification of some proposals prepared by ourselves as a synthesis that we produced from the majority of writing ${ }^{2}$ that deals with the concept of life quality or notions attached to it . This exploratory research shows that the components of the quality of life are prioritized in the following manner:

a) The cost of living;

b) The economic dynamics;

c) The services to the population ;

d) Transport and urban mobility;

e) The green spaces ;

f) Limiting pollution;

g) Cultural and sporting activities;

h) Territorial planning ;

i) The security concern;

j) The development of local identity.

In a second time, we have invited the surveyed to judge on the basis of a scale ranging from 1 to 5 (1: very insufficient (unsatisfactory); 5: very adequate (satisfactory)) the above serial variables and to justify their feeling. The main 
results that we obtained are presented in the developments that will follow.

- The cost of living in Tangier is esteemed to be higher than in other Moroccan cities. The inhabitants consider the huge gap between the wealthy who are ready to pay excessive prices and the less affluent who have no choice to avoid the high cost of goods and services.

- Constituting the second pole after Casablanca, landscaping several areas as industrial zones, establishing free zones of exportation, housing industrial Port Tangier Med, etc...The city of tangier recruits and distributes earnings in a particularly massive way thus pushing the population to consumption whose driving effects are noticeable on the economic dynamics of the whole region. Much of this active population is made up of young people coming from other Moroccan cities (one has just to spend a religious holiday in Tangier to see clearly that it is deserted!).

- Apart from the Faculties of Sciences, Faculties of Letters and Human Sciences, based rather in Tetouan, the city of Tangier had no university tradition. It had to wait the mid-1990s, with the opening of the ENCG, the FSGES and the FST, for the Abdelmalek Essaadi University to expand in Tangier. Before, families suffered to think constantly where to send their children to pursue their university studies. But if the teaching and coaching landscape is called upon to develop further in the forthcoming years, it is estimated to be below citizens' expectations in quantitative and qualitative terms whether it is primary, secondary or superior studies. Evoking the hospital sector excites the mockery of the Tangerines. It is a "joke"! They say. The parents, including those of medium purse prefer to seek treatment in Rabat or Casablanca, and wealthier ones go to
Spain or France. Many surveyed have told no that it happened to them or to someone in their family stories of serious medical errors committed by hospitals or clinics established on site. After the crisis of the 1990s, when water was scarce and the city was supplied through the sea by bringing drinkable water in large tanks, the population found again water "fluidity" with a better quality, though citizens lament its expensiveness. In fact, they estimate that the bill for water and electricity services has increased since Amendis was entrusted with their delegated management ${ }^{4}$.

- The urban mobility of Tangier operates in a comparatively particular way from other Moroccan cities. The bus lines being insufficient ${ }^{5}$, urban transport is essentially insured by :

- The "small taxis" never in sufficient availability.

- The "big taxis" cram seven people in the same vehicle, older than 30 years! (the famous Mercedes 240 D).

- Transportation of company personnel and administrations, sowing terror in roads at peak hours!, because it is entrusted to young and irresponsible drivers.

- The inhabitants of Tangier strongly regret the continuous degradation of the greenery and natural spaces that lined their city before. The housing bubble in the 2000s affected even the surroundings of the city and restricted the extent of natural landscapes where families used to go weekly for picnics.

- Accumulating tens of hundreds manufacturing companies, the city undergoes constantly green house gas fumes (GES), sewage and waste left by manufacturers and which are never evacuated in the stations of purification 
- Peopled by residents with strongly consuming habits and because of the lack of an appropriate management of urban garbage, the city of Tangier and especially the suburbs, suffer from disgusting smells and images of the ugliest imaginable household waste.

- In Tangier, many activities are extended beyond midnight. This results in a regular string of noises from vehicles and late-bidders.

- The meteorology and the reliefs of the city being unhelpful for the practice of hikes, bike drivers or rambles along a flat track, the Tangerines do not have outdoors sporting traditions. However, sport halls, though well-equipped but poorly ventilated, have developed and whose car access always remains problematic for most of them. One must admit some spaces and sports fields are prepared for the practice of physical movements or mini-foot; nevertheless, owing to the density of the population, they remain insufficient to meet the young people's expectations. As for the cultural activities, the city of Tangier has no fixed cultural appointments with the exception of the festivals of the Mediterranean Nights, the Tanjazz festival, the Avenue of FAR, the streets of Belgique, liberty, Hollande, the festival of the Amateur Theater of Tangier, etc. ${ }^{6}$ With the exception of the Ibn Batouta Club that welcomes mainly academics and some high-school pupils for revisions and exam preparations and the organization of some cultural events, the city of Tangier does not provide the young with cultural spaces that can develop in them mental capacities, activities of emancipation and personal fulfillment. Such spaces, when they exist, are provided by the private sector or by the foreign cultural centers established on site, are limited to some families because they are excessively payable. However, this acknowledged delay could be regained by the constitution in the context of Mega Tangier, municipal libraries and spaces dedicated to the youth cultural fact.

- It is said that "small is beautiful". This corresponds exactly to the city of Tangier until a more recent date. Since the starting of large building sites and particularly the port of Tangier Med, the metropolization of the city expected for 2017, the real estate bubble of the beginning of 2000 and the rural exodus, we witness a massive surge of job seekers and a dense installation of companies, creating thus a new almost haphazard configuration. Because it is a city of transit or stopover and because it is arranged to remain small, because it is also founded on small streets and a lot of "prohibited directions", including the current city center, today, the city of Tangier, cannot stand any longer the mass of vehicles that daily block it in infernal traffic jams, or even during night hours. As a result to this practically unbearable blocking, it has been recently imagined a number of solutions of transfer of much of travel traffic from the old port of the city to Tangier Med, to create Tangier Metropolis on the horizon 2017, to develop a new city center, Tangier New Center, and to transfer the coach station and the wholesale market to larger peripheral areas that are easily accessible in order to avoid the maze of the current center.

- In a city like Tangier where money flows freely thanks to drug trafficking, land speculation and illicit trade, many affluent people are interested and are dreaming of making part of it. Nonetheless, the mysteries of Tangier 
are also called illegal emigration, banditry and vandalism. As a matter of fact, the population is exposed day and night to systematic dangers of physical assaults, thefts, crimes, etc. Who can send his children to school (even close to home) without being accompanied? Who can walk in the woods even after the first light of dawn? Who can practice sport alone even in lit areas? Nevertheless, this phenomenon of insecurity is not the prerogative of solely the Tangerine city; it has widened and increased during these last years that the public authorities decided to repress all violence or disruption of citizens' peace.

- It is true that the Tangerines love their city and are very proud of it ${ }^{7}$. But this feeling is not enough; it should be accompanied by the activation of associations that can "defend" the interests of the city. In this direction, the association Al Boughaz saves no effort to preserve fiercely the cultural and identity heritage of Tangier and to raise largely the awareness of different actors concerned with sustainable development. However, the work of this association is attributed to the person who represents it, namely Rachid Tafersiti, who judges very insufficient the help provided by local actors.

\section{Conclusion}

Over the years, Tangier has taken care of its residents as well as of its non-residents because they have always been deserving, loyal and activists. Yet as it grows progressively, it tries to expand its spectrum and "to make up" its appearance, its inhabitants are lacking comfort and well-being.

\section{Marketing vis- à-vis investors}

Since it was built in the IV century B.C. by the Carthaginians ${ }^{8}$ (although the
Phoenicians were the first to establish in it their first trading post since XI century B.C.) as a business oriented city, Tangier has raised many passions (The Romans, II century B.C. ; Mauretania Tingitanturya, IV century B.C. ; Moussa Ibn Noussair in 706 and Tarik lbn Ziad in 711 ; the Idrissid, IX century ; the Fatimid, $\mathrm{X}$ century ; the Almoravides, XII century ; the Almouahides, XII ; the Portuguese in 1471 and 1640 ; the Spanish in 1480 ; Moulay Ismail in 1678 ; the British in 1857 ; the French in 1912 ; the German in 1940).

Even after it returned to Morocco in 1956 and after it lost its status as an international city in 1960, Tangier maintained freedoms of exchange and trade as well as a free zone port. After, and for four decades wear and neglect have tarnished the splendor of the city. It is only in 2003, the launch date of the Mega project of Tangier Med whose first terminal opened in 2007, that some believe that the city is planning a new configuration and has started a new economic dynamics. But the question that arises at this level is the following: does Tangier fascinate and will it fascinate as it did in the past when it had the international status?

The dynamics of investments that mark the city of Tangier is within the context of the large projects that Morocco has launched for more than ten years now. We will mention them here as they are spread over regions and cities. These are strategies of touristic development (vision 2010 and vision2020), the national initiative for human development (2005), the national pact for industrial emergence (2014-2020), the green Morocco plan (between 10 to 15 years since 2008), the national strategy for the development of logistics competitiveness (horizon 2015), the strategy Halieutis for a sustainable, efficient and competitive sector of fisheries (horizon 2020), The strategy Morocco numeric (horizon 2013), the strategic Morocco export for the development and promotion of the Moroccan exportations (horizon 2018), the emergency programs for education, professional training, and higher education (horizon 2012), the Moroccan strategy for innovation (horizon 
2014), the strategy for health (horizon 2012), the strategy for renewable energies (horizon 2020), the national port strategy (horizon 2030), the advanced regionalization (launched in 2011), etc.

Today, we like to say that Tangier is an open great work site. It is embarked in a myriad of development projects such as the building of Tangier Med (called to be the first African port and in the Mediterranean horizon 2015), the expansion and the reinforcement of the industrial zones or the creation of new ones, the establishment of new free zones, the construction of new touristic projects, the expansion and modernization of road, highway and rail infrastructure, the conversion of the port of Tangier into a marina on the horizon 2017. It is also in Tangier that was launched the program Tangier-Metropolis on the horizon 2017.

Tangier's commitment to large-scale projects is partly explained by the feeling of satisfaction left by its candidacy file for the organization of EXPO 2012.

The city of Tangier attracts all sorts of investments: industry, tourism, BTP, fisheries, etc.

Primo, industry flourishes thanks to the presence on site of big international groups (YAZAKI, VOLKSWAGEN, OPEL, AUTOMOTIVE WIRE SYSTEMS, POLYDESIGN, LEAR, AIRBUS, RENAULTNISSAN, etc.), to land and tax incentives , its openness to the Mediterranean and the Atlantic, the presence of a large European economic bloc (European Union), to its geo-strategic location, making of it a crossroads between Europe, Middle-East, America and Africa, to the abundance of its hinterland resources in terms of agricultural products and sea fisheries.

Secundo, Tangier attracts tourists thanks to its rich history as a land of meeting of civilizations, to its multiple beaches located both on the Mediterranean and on the Atlantic, to its natural, historical, cultural and archeological sites, to its hosting infrastructures, etc.
Tercio, the city of Tangier is attractive to sea fishing and aquaculture thanks to its large coastlines and port facilities, etc. Quarto, Tangier experiences an exponential expansion of BTP and its services thanks to the increase of its population.

Quinto, the city of Tangier houses many activities oriented towards foreign markets thanks to its geographical (and probably cultural) proximity of the European Union.

It is certain that the business climate in Tangier, its geo-strategic position, its economic potentialities would make of it an investment field by excellence, but it collides with a number of difficulties:

Firstly, most attracted investments in Tangier are anchored in the major projects that the Moroccan state has launched and whose horizon is distant (often 2020). Thus, as their performance assessment is not established, we must not draw hasty conclusions and as the motto of logic goes: "wait and see".

Secondly, the large investments injected in the city are of foreign origin. It is certain that the population benefits from that in terms of employment, repartition of revenues, but a technological transfer which would have long- term positive effects has not been operated yet. Besides, these investments are uncertain and depend on the world political and economic conditions and therefore their sustainability is never insured.

Thirdly, the international investment that the city of Tangier benefits from comes in bursts and often aims special crafts that require adequate preparation of human skills and competences. We must admit that since the opening of large schools (ENCG, ENSA, FST,...) during the 1990s, the training programs have produced adequate profiles for the requirements of the labor market, but given the pace and intensity of the investments, the offer in qualified human resources remains below the investors' expectations.

Fourthly, significant progress has been made in infrastructures, however, the city remains under-equipped in water, lighting, 
sanitation, land capital, telecommunications, TIC, roads, railways, connections between city and rural communes, connection between the city center and the outskirts, etc.. When such equipment exists, it does not fall within a strategic planning and lacks much visibility that it suffices that the staff of local governance change that the successor starts to reequip the city in his own way, giving thus the impression that he is bringing his own "touch" and breathing a new life.

Fifthly, until now, and in order to raise its competitiveness, Tangier has based on "the lower route" within the meaning of Porter $(1990)^{9}$, founded on the optimization of the factors of production, principally, the costs of manpower, compared to other territories. However, the "higher route" would have clearly distinguished the city from other national and international territories and benefit surely from a brand image. Thus, the city will be ready to meet the challenge of the knowledge economy, a sine qua non condition for the creation (and maintaining) of the investment. To seat an economy founded on knowledge and Research and Development, would go through the constitution of poles of competitiveness wherein professionals, research groups, experts and consultants, gurus, academics, exchange in the most fruitful way their knowledge in order to learn from each other. Tangier has not found yet the path of an "intelligent" city or that of a "learning" city!

Sixthly, the city of Tangier is lucky that we nominate in it local officials and high level executives who are particularly dynamic and animated by a strong energy to move forward. But due to lack of synchronization and overlapping of their roles, the investment promotion neither guarantees a common vision nor synergies and makes, ipso facto, the city lose much time, reflection and money. The absence of a shared vision among different local actors concerned by the investment in Tangier is due to their inability to communicate with each other, to the difference of their perceptions, to their political split, etc. In brief, the Tangerines, through their policy makers or their contractors have not developed yet a feeling for their city "cityism" that would have vivified their prosperity and radiation.

\section{Conclusion}

This axis has been devoted to the analysis of the investment attractiveness in Tangier by situating it in three stages: the stage when Tangier had the international status, the stage of the 1960s until 2000, and the stage after 2000 . The image that emerges reminds us of the "product lifecycle" in the marketers' sense which articulates the phases of "launching", of "growth", of "maturity" and of "decline", but applied to the case of Tangier, this cycle does not follow the traditional diagram. In fact:

- Between 1925 and 1975 (with the exception of the Second World War period), the city of Tangier experienced its actual golden age. Considered as one of the most important postwar financial centers of the planet, thousands of holdings ${ }^{10}$ moved to it and many billionaires came to it to squander their fortune. This massive injection of investments would unleash passions and would lead to accomplishments (or at least entertainment!), ennoblements (or at least enrichments!), blooming (or at least embellishments).

- Losing its cosmopolitan essence and its international status since 1960, a fatal "parenthesis" opened and contractors started to desert the city and the investment started a period of continuous melting like snow under the sun. There was at the outset a slow-down followed by a shrinking. Then it underwent "amortization" until "annihilation", let alone downright disinvestment.

- Enjoying a resurgence of interest on the part of public authorities, since the years 2000, the investment in Tangier experienced rejuvenation. By force of their new outpouring, projects reached precociously their flourishing.

- The entry into service of Tangier Med since 2007, the marina projection on 
the horizon 2015 and the launching of the Tangier Metropolis between 2014 and 2017, and the definition of other more linked projects, testify to a great boldness and deserve applause. However, the economic investments are not sufficient. They must be accompanied by an investment in the mentalities. We believe that only ardor, supervision and consultation feed the investment in order to reach its maturity.

\section{Marketing vis- ̀̀-vis tourists}

Tourism in Tangier falls within the framework of the Plan Azur which aimed to attain 10 million tourists on the national scale on the horizon 2010 (by creating among others, the sea-side resort Lixus in the region of Tangier-Tetouan). In addition to the signature of the agreement Open Sky (Cielouvert) end 2006 which had for purpose the entry of tens of airline companies including the Low cost (Rayanair, Easy Jet, Atlas Blue, Jet 4 You).

The vision 2020 has for ambition to " hoist Morocco among the first twenty world touristic destinations while establishing itself as a reference destination in terms of sustainable development on the Mediterranean region ${ }^{11}$ ". The implementation of this strategy is ensured by the identification of a cartography of eight territories. Among these the Cap Nord is composed of 5 provinces of the region Tangier-Tetouan (provinces of Chefchaouen, Fahs-Anjra, Larach, Tetouan and Ouezzane) and the prefectures of Tangier-Asilah and Mdiq-Fnideq ${ }^{12}$. The Tangerine region, "meeting point" between the Atlantic Ocean and the Mediterranean Sea, and between Africa and Europe, "conceals a natural, cultural, rich and original heritage, with especially its Medina, its Hercules caves, and the beaches of Cap Spartel and Cap Malabata"13. Indeed, Tangier is endowed with a number of touristic assets such as its touristic roots, its archeological and historic sites, its natural sites and resorts, its two seaboards, its Lixus hosting station, its marinas, its future promises for new touristic segments ( cultural, ecological, rural, sports tourism). It should be noted here that the most privileged touristic sites by tourists are essentially the Great Mosque, the Tangier museum of contemporary art, the museum of Fondation Lorin , the museum of the American Legation of Tangier, the Casbah museum, the Petit Socco (small market), the Mendoubia, the Grand Socco (big market) and the Café Hafa. Besides, Tangier and its hinterland are endowed with a great diversity of natural environments: coastline and marine environments, wetlands, mountainous areas, forests, natural parks, etc...

The region of Tangier is more and more attractive insofar as it is easily accessible because it is served by all sorts of transport: maritime, air, road and train.

Tangier is also known for its exceptional artistic and cultural dynamism. It has the merit of hosting every year cultural events of international scale such as the festival of the Mediterranean nights, the Tanjazz festival, avenues of FAR and Bourguiba, the streets of Belgique, la Liberte, Fes and Holland, the international book fair of Tangier, the architecture, Housing and real estate fair, the international festival of amateur theater of Tangier, etc..

Tangier is currently characterized by a great ability to drain colossal investments and highly reputed operators, namely the project of Houara, the Tangier City Center housin complex, Royal Resort Cap Malabata, Cap Tinja, Ghandouri project, the Chaabi littoral Group, Holmarcom Group, etc...

If in the eyes of the officials in charge of the city governance, the efforts that have been made up to now are laudable and promising, it remains that the citizens, actors or visitors who were subjects to our investigations point out some gray areas that we would like to emit synthetically in the following developments.

Primo, it is certain that Tangier presents enormous possibilities, but they are not sufficiently exploited. Due to its international status that it enjoyed in the past, Tangier was the most coveted national destination. Since, it has lost its leadership in this area to switch to the fourth rank behind Marrakesh, Agadir and 
Casablanca. In fact, the Tangier-Tetouan region shows relatively low values in terms of accommodation capacities. With its 66 rated hotels (35 in Tangier) which represent $10 \%$ of all the units at the national level, its three touristic holiday villages (one in Tangier), its four touristic residences ( 2 in Tangier), the region is largely situated behind that of MarrakeshTensift-El haouz and Souss-Massa-Daraa.

Secundo, the efforts of the valorization of Tangier touristic potential face climate problems which accentuate the seasonal nature of the sector and make difficult the amortization of the equipment especially major one. The challenge for Tangier is to diversify the customers and to position on strong, diversified and complementary segments. According to the documents that we have made census of and which treat the perception of tourism, it seems that the latter is segmented into sub-sectors to which we have different interests. On a scale of ten points, the segments resort, business, cruises, cultural, ecological, sports and leisure are graded respectively $8 / 10,6 / 10,5.4 / 10,5.2 / 10,4.2 / 10$ and $3.2 / 10$. Thus, concentrating its attention on the seaside, Tangier does not know how to manage the seasonality of this segment and therefore has a substantial shortfall. Furthermore, when it comes to international tourism, the offer is generally either inadequate with relation to the desiderates of the visitors of the region by lack of leisure and animation activities; or inaccessible (particularly in summer period) by deficiency (and expensiveness!) of aerial or maritime connectivity.

Tercio, we would not evoke tourism in Tangier without calling up to mind pollution in all its

Facets (greenhouse gas, noise and visual pollution because of "concrete" which grows everywhere like mushrooms preventing us from contemplating the scenery and the charm of the city).

Quarto, it must be noted the absence of some techniques and the touristic marketing strategy (insufficiency of signalization, of information and promotion, non integration in the most marketed touristic circuits or in tour operators, absence of a specific theme or label, insufficient effort of communication and promotion, absence of customer loyalty, etc..). This marketing deficiency has pushed the region to a coriaceous competition on the part of other touristic destinations presenting relatively similar offers or having identical targets. To this wild competition is added the loss of customer countries, particularly the British, the Americans, the Germans and the Italians who have deserted the city knowing that in the past They were regulars of the city.

Quinto, finally, it is worth emphasizing that the image of Tangier suffers from a negative perception due especially to its border character and to its association with the Rif region where the culture of cannabis reigns, and to the presence of illicit activities like smuggling, the alcohol or illegal emigration

\section{Conclusion}

When we look deeply at the historical track of tourism in Tangier, we note that it has indeed often been associated to a sort of "adventure" and that its future projection calls for a real disruption. Falling within the past amateurism, it is today conducted an adventurism and remains at the mercy of entryism. Thus, each time Tangier wishes to build its brand image it comes up against misunderstandings and prisms. In transposing the approach and marketing tools to it and by including it in the geo-centrism, and since it is resolutely heading towards the futurism and facing the mounting power of consumerism, the officials of the Tangerine touristic fact are invited to innovate to drain and to know how to receive visitors in the city or at least follow the trend that would obviously be only eco-tourism.

General conclusion: Badly "rated", Tangier needs to be "marketed"

Eager to fit our research in a normative approach and anxious to anticipate the future trend, we would like to produce in 
the following developments some recipes liable to make the marketing of the city of Tangier succeed better. Despite our estimation of the ability to transpose such recipes to other Moroccan cities, we do not pretend at all that they constitute a panacea since the answer to urban concerns is undeniably conditioned by the spatiotemporal context.

\section{- Networking with other cities}

It is relations with either national or foreign cities that are maintained on specific themes (gastronomy, light, technology, art, diaspora, heritage, sustainable development, ...), the goal, according to B. Meyronin ${ }^{14}$, is to constitute a platform of exchanges and sharing of good practices through forums, working groups, collective projects, publications...But its purpose is also to contribute to city dialogue with European institutions. Such "cooperation would contribute to the radiance of the territory on a supra regional scale ".

\section{- Creation of the brand}

Generally, the identity of a brand means ..." what has always characterized us in a singular fashion and in all our products and acts"15. By transposition 16 to territories, the brand identity of a territory consists in associating perceptions, and attractive, distinctive and positive values. It contains $^{17}$ :

○ "profits" both tangible and intangible, at the same time for residents, tourists and investors, and this by seeking a specialization as rare as possible ;

o a distinctive personality from the other territories even by inventing "nicknames" which would stick to its advantages ;
- a brand culture that could mean i. the identification signs of the quality and the origin (such as the mandarin of Berkane, the anchovy of Al Hoceima, Olive oil of Ouazzane, ...) ; ii. the "country brand" touting the vocation of a whole nation and whose promotion is provided by public or para-public organisms ( such as Investir au Maroc (invest in Morocco), l'Office National du Tourisme (National tourist office)) ; iii. The "made in" which would value an offer by means of its geographical origin whose competences are real or imaginary (such as saffron made in Morocco); iv. The brand of the poles of competitiveness which would have gathered in a territory a company of the sector known for an art, a know-how or a precise specialization.

- Physical elements of recognition whether are atmospheric conditions (reliefs, climatology, seas, ...) or men's profile ( pottery of Safi, leather goods of Fes, Marrakchis' reception, trade of the Soussis, ...)

\section{- Use of territorial celebrities}

It is to call on to famous personalities associated with the territory ( it is difficult to dissociate Tangier Ibn Batouta, the Rif region of Abdelkrim Khattabi, Hicham El Guerrouj of Berkane, Benissa of Asilah, etc.) personalities who marked their territories whether they pertain to culture, sport, science, economy or business). Even sometimes fictive characters are mobilized to communicate the image of a city (the case of Hercules in Tangier for example)

\section{- Quest of labels}

They are titles granted as a sign of recognition to the effort made by a city in a given domain (the case of Rabat considered as "world heritage of culture" by the UNESCO, of Fes for its spiritual music, of 
Agadir for its music of tolerance, of Tangier for its jazz music, of Oualidia labelized with the eco-label "Blue Pavilion" for its clean beaches, titles granted by Mohammed VI foundation for the protection of the environment and the international foundation for the education and the environment, of Tangier under the status of international zone, of Moulay Yacoub known for its thermal stations, etc.)

\section{- Association of territorial marketing to sporting events}

As sport activities are appreciated all over the world, cities have waged a wild competition for the organization of periodic sports events by operating a targeting of a sport that distinguishes them from each other. It is the case of tennis associated with Rolland Garos (Paris), the week of the horse (Rabat), formula I (Dubai).

\section{- Communicational activation}

Having recognized the weight of the regions in politico-economic and sociocultural development of the nations, the specialists knew how to exploit a new field of communication ${ }^{18}$. In Morocco, and since the royal speech of 09 March 2011 on the advanced regionalization, different communications were established to impart the sources of inter-regional complementariness and cohesion. Haven't we considered the Oriental region and the Rif as a sort of regional crossroads between Europe and the Maghreb? Haven't we estimated Souss Massa Draa as a champion of enterprising spirit? Haven't we called Tangier the pearl of the Straight? But we have to indicate that these glued images to territories (regions or cities) are generally conceived by agencies of economic development and regional centers of investment and are inherited from occasions of sporadically organized festivals or debated in the columns of certain local or regional press. These images are not yet the fruit of a service or commune structure dedicated to tout their virtues and merits. Moreover, the advertising discourses often address the investors and tourists and lack proximity towards residents; unless we count some sensitizing campaigns for the citizens about the cleanliness of the urban space or that of some beaches during summer period; and these campaigns do not fall within the regular current of conduct. Yet, and for efficiency concerns, we perceive more and more communications that mobilize the population such as the training and coaching of the guides, sensitizing of restaurateurs, hoteliers, and store managers to know how to receive tourists.

\section{- Creation of a territorialized know-how}

In order to enhance the territorial competitiveness in highly innovative domains, countries have embarked on the poles of competitiveness. The installation of the latter repositions differently the regions. Thus, they place directly their competition on the international scene instead of competing solely on the national scale. The extrovert vision of a territory tends thus to shorten the systematic learning process. The history of the poles of competitiveness started with the writings of Alfred Marshall who spoke about the "industrial districts", but also Michael Porter's works who preferred "clusters" instead. These reflections have had an echo on the field with the successful case of Silicon Valley, as a territory devoted entirely to the American computing and microelectronics production. The success of this new territorial dynamics is founded on the collaboration between the components of the cluster. 


\section{- Creation and maintenance of cultural system}

The culture of a territory is presented as an inherited richness ${ }^{19}$, an event associated with precise or shifting dates and projecting into the future ${ }^{20}$. It results in feasts, festivals, sporting events, contemporary creation, etc. Because it permits to restore confidence to citizens and make them proud of their territory, culture flourishes even in periods of economic crises. The concerts of Mawazine (Rabat), Jazzablanca (Casablanca) and Tanjazz, Twiza, university theater or film (Tangier).

\section{- Reinvention of territorial marketing}

By concerns of durability, cities are heading more and more towards sustainable development ${ }^{21}$.

By concerns of innovation and renewal of territories ${ }^{22}$, companies or territorial collectivities cannot work separately and wonderfully, they are called to search for fields of convergence so as to redefine public-private partnership.

Seeking an international brand image ${ }^{23}$, territories are getting gradually loose from their old logic anchored in their own space to explore others. That is what has permitted to the Louvre and the Sorbonne for example to settle in The United Arab Emirates, or the exportation of institutions from Lyon to Dubai City (precisely the exportation of social and human sciences of University Lyon 2, the gastronomy of Paul Bocuse Institute, the football of l'Olympique Lyonnais, the cinema of Lumiere Institute, fashion and the creation of Cloth museum, the management of l'EM Lyon).
Besides, we must observe that new urban configurations are hovering on the horizon chiefly at the level of some wastelands and disaffected port or industrial zones to which are assigned new roles such as shopping, leisure or culture ${ }^{24}$. This is testified by the old port of Tangier which is projected to be on the horizon 2015 rather a marina of leisure, shopping and culture.

Finally, we must mention here the fact that all the options above would be relevant only if territories were endowed with structures devoted to territorial marketing. These structures would develop the reflex to answer (and satisfy) the expectations of users of local public service, with a supplementary condition of inviting citizens to take part in the coproduction of the territorial offer, of its communication and the contribution to the radiance of their territory image.

Our research intends to be global insofar as we have studied simultaneously the territorial marketing as it addresses residents, tourists, and investors. These three types of marketing involve actors with divergent horizons, mobilize energies with different intensity and undertake strategies with distinct visions. Thus, we plan to pursue our investigations pulling apart each user as determined by territorial marketing.

\section{Notes}

1 Revue Economie \& Entreprises, Quelle stratégie marketing pour un développement durable?, Forum du manager, $n^{\circ} 65$, Novembre 2004.

2 Including ourselves.

3 Different theoretical writings and practices prefer to talk about sustainable 
development, but for fear of not knowing the meaning of the term, and because sustainable development is reflected ultimately in the quality of life, we have adopted the latter term.

4 A subsidiary of Veolia Environment, responsible for managing the water and electricity in the region Tangier-Tetouan.

5 These lines are assigned to a single company operating only for a few years!

${ }^{6}$ See infra.

7 While remaining open to national subcultures and foreign cultures, in view of the diversity and human mixture that have marked the city forever.

8 M. Laaboudi, Tanger, Librairie nationale, 2010.

9 Porter M., L'avantage concurrentiel des nations, 2d. Du Renouveau pédagogique, 1993.

10 Version Homme (VH) magazine, $\mathrm{n}^{\circ} 92$ Novembre 2010.

${ }^{11}$ National Touristic Strategy 2020 vision.

12 Idem.

13 Idem.

14 B. Meyronin, Marketing territorial : enjeux et pratiques, Vuibert, 2ème édition, 2012.

$15 \mathrm{~J}$-N. Kapferer, Les marques, capital de l'entreprise, Eyrolles, les Editions d'organisation, collection "références", 4 ème édition, 2007.

16 D. Merunka\& A. Ouattara, «La ville en tant que marque: métaphore ou réalité », Actes du 7ème colloque Ville-Management, in www.ville-management.org, 2006.

17 Agefi, Gérer les villes comme des marques, numéro du 25 septembre 2002.
18 D. Megard \& B. Deljarrie, La communication des collectivités locales, LGDJ/Dexia, collection Politiques locales, 2003.

19 B. Graham, "heritage as knowledge: capital or culture ?", Urban Studies, 39, n 10, 2002.

20 X. Greffe, La mobilisation des actifs culturels de la France. De l'attractivité culturelle du territoire ... à la nation culturellement créative, rapport de synthèse sur l'attractivité culturelle, ministère de la culture et de la communication, document de travail du DEPS n 1270 , mai 2006.

${ }^{21}$ P. Ingallina \& J. Park, « city marketing et espace de consommation: les nouveaux enjeux de l'attractivité urbaine", revue Urbanisme, $\mathrm{n}^{\circ}$ 344, septembre-octobre, 2005.

22 V. Cova \& B. Cova, Alternatives marketing, Dunod, 2001.

23 J-N. Kapferer, op. cit.

${ }^{24}$ L. Davezies, «Développement local : le déménagement des Français. La dissociation des lieux de production et de consommation », Futuribles, n² 295, 2004

\section{References}

1. Agefi, Gérer les villes comme des marques, numéro du 25 septembre 2002.

2. V. Cova \& B. Cova, Alternatives marketing, Dunod, 2001.

3. L. Davezies, «Développement local : le déménagement des Français. La dissociation des lieux de production et de consommation », Futuribles, n 295, 2004.

4. V. Girard, Contribution à l'étude du marketing territorial : le cas des projets de ville et d'agglomération française, thèse de doctorat, Université Lyon 3, 1999.; J-P. Flipo \& L. Texier, Marketing territorial : de 
la pratique à la théorie, Revue Française du Marketing, $\mathrm{n}^{\circ} 136,1992$.

5. B. Graham, "heritage as knowledge: capital or culture ?", Urban Studies, 39, ${ }^{\circ}$ 10, 2002.

6. X. Greffe, La mobilisation des actifs culturels de la France. De l'attractivité culturelle du territoire ... à la nation culturellement créative, rapport de synthèse sur l'attractivité culturelle, ministère de la culture et de la communication, document de travail du DEPS n 1270 , mai 2006.

7. F. Hatem, Le marketing territorial: principes, méthodes et pratiques, éd. EMS, 2007.

8. P. Ingallina \& J. Park, « City marketing et espace de consommation: les nouveaux enjeux de l'attractivité urbaine ", revue Urbanisme, $\mathrm{n}^{\circ} 344$, septembre-octobre, 2005.

9. J-N. Kapferer, Les marques, capital de l'entreprise, Eyrolles, les Editions d'organisation, collection "références », 4ème édition, 2007.

10.M. Laaboudi, Tanger, Librairie nationale, 2010.

11.Lendrevie J. et Lévi J., Mercator : théories et nouvelles pratiques du marketing, Dunod, 2013.

12.G. Lorant, Les collectivités locales face aux défis de la communication, L'Harmattan, 2006.
D. Megard \& B. Deljarrie, La communication des collectivités locales, LGDJ/Dexia, collection Politiques locales, 2003.

13.D. Merunka \& A. Ouattara, «La ville en tant que marque: métaphore ou réalité », Actes du 7ème colloque Ville-Management, in www.ville-management.org, 2006.

14.B. Meyronin, «Marketing des services publics et marketing territorial : vers une dynamique de ré enchantement?», Economies et Sociétés, série Economie et gestion des services, EGS, ${ }^{\circ}$ 9, 2, 2008.

15.B. Meyronin, Marketing territorial:

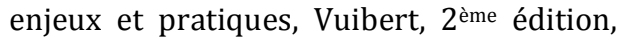
2012.

16. Ministère de tourisme, Stratégie touristique nationale vision 2020 .

17.Porter M., L'avantage concurrentiel des nations, 2d. Du Renouveau pédagogique, 1993.

18. Revue Economie \& Entreprises, Quelle stratégie marketing pour un développement durable?, Forum du manager, $n^{\circ} 65$, Novembre 2004 .

19. Revue Economie \& Entreprises, Tanger : le grand Ménage, supplément Tanger, $\mathrm{n}^{\circ}$ 75, Octobre 2005.

20.Version Homme (VH) magazine, $\mathrm{n}^{\circ} 92$ Novembre 2010. 